\title{
A cidade de São Paulo e suas dinâmicas: graffiti, Lei Cidade Limpa e publicidade urbana
}

The city of São Paulo and its dynamics: graffiti, Clean City Act and urban advertising

\section{ELENA MORAES PIRES}

Universidade Federal de São Paulo / Osasco, SP, Brasil

\author{
FÁBIO ALEXANDRE DOS SANTOS² \\ Universidade Federal de São Paulo / Osasco, SP, Brasil
}

RESUMO: A interpretação da sociedade sobre o caráter do graffiti tem mudado devido à legislação e à disseminação de murais de graffiti pela cidade de São Paulo, alguns incentivados pela Prefeitura. Obras têm sido espalhadas com o objetivo de embelezar a cidade e valorizar pontos turísticos, favorecendo o reconhecimento e a popularidade de grafiteiros e fomentando uma economia do graffiti, hipótese que norteia esta investigação. Desta forma, o objetivo geral deste artigo é refletir sobre como essa "economia" tem incorporado o graffiti aos interesses do mercado, demonstrando que esse processo de incorporação criou formas de "contornar" as limitações à propaganda impostas pela Lei Cidade Limpa, as quais têm sido empregadas por grandes empresas e agências de publicidade.

PALAVRAS-CHAVE: Grafite. Arte. Lei Cidade Limpa. Política pública. São Paulo.

ABSTRACT: Legislation changes and the dissemination of graffiti murals has changed the interpretation of society about the character of graffiti in the city of São Paulo, even receiving some encouragement from the City Hall. Graffiti pieces have been spread to embellish the city and promote touristic spots, which has favored the recognition and popularity of graffiti artists, encouraging a graffiti economy. The general objective of this article is to reflect on how this "graffiti economy" has been incorporated by market interests, showing that such incorporation

1. Graduada em Ciências Econômicas pela Escola Paulista de Política, Economia e Negócios (EPPEN), da Universidade Federal de São Paulo (Unifesp), campus Osasco. E-mail:<nenamoraes@ hotmail.com>

2. Professor do Departamento de Economia e do Programa de Pósgraduação em Economia e Desenvolvimento da Escola Paulista de Política, Economia e Negócios (EPPEN), da Universidade Federal de São Paulo (Unifesp) e Pesquisador do Laboratório de Estudos Interdisciplinares e Análises Sociais (Leia) da EPPENUnifesp. E-mail: <fa. santos@unifesp.br> 
3. Gitahy (1999); Sales (2007); Campos (2007); Pimentel (2012). process led to the creation of ways to "circumvent" advertising limitations imposed by São Paulo's "Clean City Act" (Lei Cidade Limpa), which led to graffiti murals being used by big companies and advertising agencies.

KEYWORDS: Graffiti. Art. Lei Cidade Limpa. Public policy. São Paulo.

\section{INTRODUÇÃO}

Com pessoas e realidades sociais distintas, as cidades revelam cenários ricos e diversificados, que ao mesmo tempo podem aumentar os contrastes das desigualdades sociais. Sob esse contexto urbano surgiv o graffiti, como manifestação das ruas, configurando-se essencialmente pela pintura nos espaços urbanos construídos, constituindo uma forma de arte e protesto em face das desigualdades sociais, dando voz e expressão a sujeitos que muitas vezes não tinham meios suficientes para exprimi-las. ${ }^{3}$

Inicialmente, a natureza transgressora do graffiti foi encarada pelo Estado como vandalismo do espaço público e um perigo para a conservação da propriedade privada, devendo, portanto, ser combatido. Com o tempo, contudo, essa concepção marginal transformou-se, incidindo numa valorização aceitável pelo Estado e positiva pela sociedade. Essa transição do graffiti, de uma arte marginal para uma manifestação artística reconhecida e aceita, tem revelado aspectos importantes não só para os profissionais do graffiti, mas para a sociedade como um todo, pois incorpora a possibilidade de ser um produto artístico de valor cultural, econômico e ideológico, apto a beneficiar a todos: os grafiteiros, a administração pública, a economia e a população urbana. Porém, não sem conflitos e contradições. 
Como manifestação cultural, o graffiti e os fatos e acontecimentos dele decorrentes revelam o conjunto da realidade social. Por isso, é preciso apreendê-lo em suas dinâmicas, contradições, avanços e recuos, que se dão sob o contexto da lógica capitalista, como destaca Kellner, sob a forma de materialismo cultural; mais especificamente, no centro do que Williams chama de "ordem social geral". 4 De acordo com Kellner, as manifestações artísticas são parte do processo de produção, distribuição e consumo, ou seja, níveis da realidade social em que são produzidos e consumidos.

a produção da mídia está, portanto, intimamente imbricada em relações de poder e serve para reproduzir os interesses das forças poderosas, promovendo a dominação ou dando aos indivíduos força para a resistência e a luta. Mas o materialismo cultural também focaliza os efeitos materiais da cultura da mídia, insistindo em que suas imagens, espetáculos, discursos e signos exercem efeitos materiais sobre o público. Para o materialismo cultural os textos da mídia seduzem, fascinam, comovem, posicionam e influenciam seu público. ${ }^{5}$

A partir dessas hipóteses, este artigo considera que a ascensão dessa atividade artística tem sido absorvida pelo mercado, adquirindo características de negócios na cidade de São Paulo - fomentando uma economia do graffiti -, com desdobramentos para além da própria manifestação artística. ${ }^{\circ}$ No contexto dessa atividade econômica torna-se tema de debate a ressignificação do trabalho do grafiteiro, além de alterar funções do Estado e de grandes corporações diante dessa ressignificação.

objetivo geral desse artigo é estudar o modo como o graffiti tem sido incorporado pelo mercado, especificamente apontando formas e conflitos que permeiam essa incorporação, visto que, em São Paulo, o graffiti tem sido utilizado como meio para "contornar" a Lei n 14.223/06, conhecida como Lei Cidade Limpa.

Isso implica uma análise que abrange as relações do graffiti não só com o mercado privado, mas também com o Estado, na medida em que este criou as condições para a legalização da atividade, diferenciando-o da pichação; porém, ainda esbarrando na carência de legislação e regulamentação específica sobre o que seria considerado arte, onde se expressar e com autorização ou não dos poderes públicos.

No caso da cidade de São Paulo, essas questões representam obstáculos diretamente ligados às diferentes gestões dos prefeitos que a administraram. No centro dessas relações, ao longo dos anos, a investigação detectou avanços e conquistas para os grafiteiros e para a sociedade, mas também muitos conflitos e tinta cinza a cobrir graffitis pela cidade, muitas vezes arbitrariamente.
4. Williams (1992, p. 12).

5. Para Kellner (2001, p. 63), o estudo das manifestações culturais abarca a análise da natureza e das formas de produção da indústria cultural e sua distribuição. Daí o conceito de "cultura de mídia" para designar a relação dialética entre cultura e comunicação, evitando oposições como "cultura popular" ou "cultura de elite", ou "cultura de massa" (Kellner, 2001, p. 52).

6. Pires (2016).

7. Onde se materializam as trocas, sendo a mercadoria-dinheiro utilizada como equivalente de valor pelos indivíduos, na medida em que esses mesmos indivíduos efetivam as trocas e "não têm nenhum vínculo pessoal com as coisas que possuem; incluindo relações sociais 'de alheamento mútuo', exclusivas do capitalismo" (Harvey, 2013, p. 48-63). 
8. Cidade Cinza (2013) é um documentário dirigido por Marcelo Mesquita e Guilherme Valiengo, que retrata um processo de limpeza urbana iniciado em 2008, quando a Prefeitura de São Paulo passou a pintar de cinza os muros com pichações. Os graffitis também foram alvos da tinta cinza.

9. Gitahy (1999).

10. Assinatura do grafiteiro no muro.
Para fundamentar este artigo, que é parte de uma investigação mais ampla sobre a geração de uma "economia do graffiti" na cidade de São Paulo, realizamos a leitura da bibliografia que trata do tema, seguida de levantamento e leitura de artigos publicados em periódicos e notícias. A análise da produção normativa (regulamentação e propostas de regulamentação direta e indiretamente relacionadas ao tema) foi fundamental para identificar as especificidades, as discussões e as lacunas existentes na atividade e na sua gestão por parte dos poderes públicos. Além disso, foram consultados textos e sites relacionados à temática, de origem pública e privada. Finalmente, foram realizadas entrevistas semiestruturadas com pessoas que trabalham diretamente com graffiti, de grafiteiros a funcionários da Prefeitura de São Paulo (que atuam ou ałuavam na gestão do graffiti em São Paulo).

Destacamos, por fim, que o recorte temporal estabelecido neste artigo tem início com as primeiras manifestações artísticas relativas ao graffiti, em Nova lorque, e sua disseminação a partir dos anos 1980 - impondo, inclusive, o início da discussão sobre a gestão da paisagem urbana pelos poderes públicos em São Paulo - e se encerra nos dois primeiros meses da gestão João Dória Júnior (2017), que ao assumir a Prefeitura iniciou a operação chamada "Cidade Linda" e, com ela, inaugurou uma nova onda de supressão de graffitis pela cidade, ocasionando novos episódios conflituosos entre Prefeitura, grafiteiros e sociedade.

\section{O GRAFFIT: ORIGENS, ESPECIFICIDADES E DIFUSÃO}

O graffiti se baseia em uma técnica de pintura em espaços públicos ou privados com tintas e sprays expressando-se por meio de figuras abstratas ou representativas, podendo também incorporar palavras estilizadas. As primeiras manifestações do graffiti contemporâneo ocorreram em Nova lorque, junto com o movimento musical do rap, do hip-hop e do break dance, sendo a expressão "escrita" desse movimento. Essa manifestação cultural e estilística se espalhou pelas principais metrópoles do mundo. ${ }^{8}$ Era uma forma de registrar, sobre o espaço da cidade, os fatos, as posições e os conflitos que permeiam a realidade social. ${ }^{9}$

Paralelamente ao movimento que despontava em Nova lorque, o graffiti surge nas metrópoles brasileiras como uma arte transgressora. Inicialmente marcado pela prática de se deixar o nome ou a marca do executor, sua tag, ${ }^{10}$ o graffiti logo se desdobrou como expressão artística, trazendo releituras e discussões sociais e políticas, transgredindo os espaços públicos de maneira gráfica e espontânea, 
muitas vezes com o objetivo de dar visibilidade e trazer reconhecimento ao artista, ao mesmo tempo despertando a reflexão dos transeuntes. ${ }^{11} \mathrm{Na}$ cidade de São Paulo, tal manifestação tomou as ruas e adquiriu suas características criativas próprias, principalmente nos estilos de letras empregados. ${ }^{12}$

No entanto, o graffiti, muitas vezes foi confundido com a pichação; por isso, faz-se necessário diferenciá-los:

Uma das diferenças fundamentais entre o graffiti e a pichação é que o primeiro advém das artes plásticas e o segundo da escrita, ou seja, o graffiti privilegia a imagem, enquanto a pichação, a palavra e/ou a letra. ${ }^{13}$

Tanto o graffiti quanto a pichação acontecem em muros públicos, pontes, tapumes, túneis, fachadas e empenas cegas ${ }^{14}$ de prédios (Figura 1), basicamente podendo ocupar qualquer espaço público, ou até mesmo privado, que possa ser preenchido.

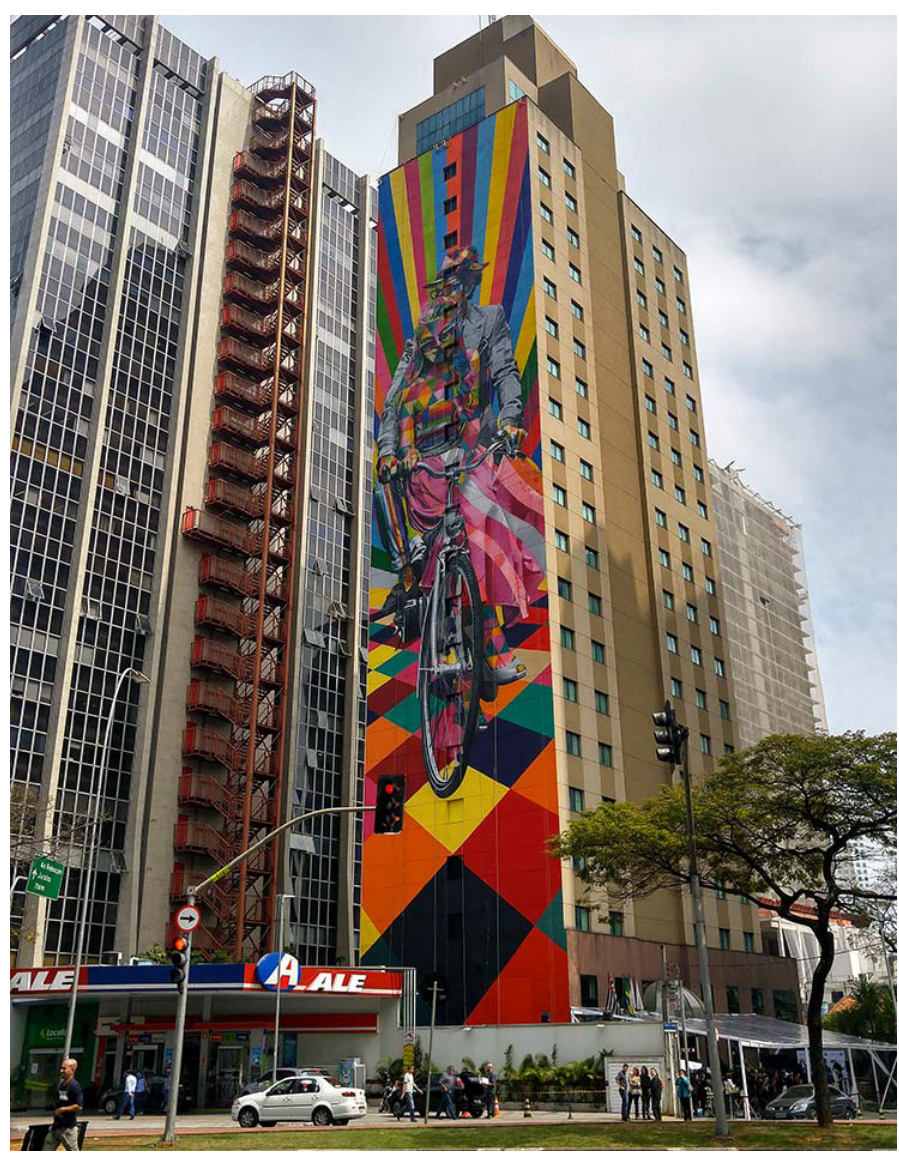

Figura 1 - Empena com graffiti Ciclista, de Eduardo Kobra, na avenida Faria Lima, São Paulo, 2016. Fonte: site Esse mundo nosso. Fotografia de Fernando Brisolla.
11. Sales (2007, p. 3).

12. Efemeracidade (2013).

13. Sales (2007, p. 4).

14. Empena cega: parede lateral externa de um prédio que não possui janelas ou ventilação. 
15. Sales (2007, p. 4-6); Pimentel (2012, p. 2).

16. Moraes (2013, p. 24).

17. Silva e Silva (2015). O graffiti teve sua primeira exposição de expressão em 1975, no Artist's Space, em Nova Iorque. Na ocasião, foi apresentado Peter Schjeldahl, cuja consagração aconteceu em 1981, com a New York-New Wave. Outro nome expressivo no contexto da consolidação do graffiti em Nova Iorque foi Jean-Michel Basquiat, que no final da década de 1970 chamou atenção pela expressividade "poética que deixava nas paredes dos prédios abandonados de Manhattan”. Em seu trabalho, Basquiat abordou temas como genocídio, opressão e racismo (Ivo, 2007, p. 113).

18. Uma iniciativa independente, chamada Revivarte, com a colaboração dos grafiteiros Fel, Mundano, Rmi e Subtu, coloriu e decorou os prédios e imediações do Parque do Gato, no centro da cidade, promovendo também oficinas de arte para crianças e jovens da comunidade.

19. Entre 2009 e 2011 , ocorreram cerca de três exposições no Masp (Museu de Arte de São Paulo) com a temática graffiti (Masp, 2010).

20. Boemer (2013, p. 36)

21. Por exemplo, Gustavo e Otávio Pandolfo, Os Gêmeos, ingressaram no mundo do graffiti a partir do hip hop paulistano, na década de 1980, e com estilo peculiar conquistaram espaço em importantes circuitos do graffiti no mundo, expondo em importantes galerias privadas e espaços públicos.
A diferenciação entre graffiti e pichação é uma especificidade brasileira, pois enquanto em sua origem norte-americana o conceito de graffiti se referia a ambas as práticas, no Brasil o graffiti em geral está associado apenas à prática do desenho, e a pichação refere-se apenas às palavras com mensagens "subversivas". ${ }^{15}$ Enquanto o graffiti se aproxima cada vez mais do que se considera arte contemporânea, ganhando popularidade e sendo apropriado pelo universo privado, o picho continua vinculado à ideia de "sujeira", vandalismo, transgressão e marginalização. ${ }^{16}$

Historicamente, também houve uma transição dos sprays dos espaços públicos para os privados. Segundo Silva e Silva, foi já na segunda metade da década de 1970 que esse caminhar teve início. Sua gênese explica-se pela "euforia" gerada pelo grafitti nos espaços públicos, motivando sua incorporação às galerias de arte e, mais do que isso, sua entrada no circuito artístico das elites econômicas e sociais, "legitimando um espaço de afirmação social para o grafite urbano contemporâneo". ${ }^{17}$

Guardadas as especificidades de cada cidade, vale destacar que o graffiti tem sido cada vez mais utilizado como instrumento de políiticas públicas, decoração de espaços públicos, peças publicitárias e pinturas de fachadas de prédios sob encomenda ${ }^{18}$ ou, ainda, sendo exposto em museus de arte, ${ }^{19}$ proporcionando visibilidade e renda aos grafiteiros.

Boemer argumenta que de certa forma essa disseminação em locais socialmente aceitos, como em museus e em produtos de consumo em massa, tem resultado na apropriação do graffiti pelas classes mais altas da sociedade, - que tem "domesticado" o graffiti, desvirtuando sua característica intrínseca de transgressão e manifestação periférica e esvaziando seu significado histórico e social. Apesar disso, argumenta o autor, a ocupação dos lugares públicos de maneira ilícita continuará existindo, tanto por pichadores quanto por grafiteiros, já que os pichadores não têm nenhuma pretensão de serem aceitos socialmente, visto que sua intenção é ocupar as ruas e serem subversivos. ${ }^{20}$

Em contrapartida, o graffiti ao ser valorizado por seu caráter "embelezador" e/ou "não transgressor", possibilita que grafiteiros sejam reconhecidos e, com tempo e dedicação, construam carreiras sólidas, atuando à sua maneira e estilo, com independência, a exemplo de Os Gêmeos e de Eduardo Kobra, reconhecidos e valorizados por seu estilo. ${ }^{21}$

Há uma multiplicidade de estilos e motivações que assinalam os grafiteiros nesse universo. De acordo com lvo, que destaca a complexidade dessa abordagem, 
há inúmeras peculiaridades nos estilos, nas expressões, nas condutas e motivações dos grafiteiros, o que dificulta definições. Elas diferem de lugar para lugar, de cidade para cidade, refletindo as condições de vida de cada um dos artistas. Por isso, do ponto de vista da expressão artística, as "obras", as "problemáticas" e os "questionamentos" retratados pelos grafiteiros revelam pluralidades e conflitos diversos, diferentes expressões e representações e diferentes relações com o espaço em que vivem e se manifestam. ${ }^{22}$

Segundo o grafiteiro Thiago Vaz, há entre seus companheiros de graffiti aqueles que se dedicam a uma gama mais ampla de trabalhos e aqueles que não. Entre os que optam por diferentes mercados, estão os grafiteiros que vendem seus trabalhos para galerias, por exemplo em forma de quadros ou itens colecionáveis. Vaz destaca que entrar nesse circuito é mais fácil para alguns artistas, que se pautam majoritariamente na pintura ou na decoração; por outro lado, há aqueles que se reconhecem ideologicamente por suas obras, não aceitando qualquer trabalho ou proposta:

Eu tenho uma característica diferente, [...] eu não faço trabalho para vender. [... A A minha proposta é de fazer o trabalho em espaço público, para exibir. Vai ficar por um período. Vender, eu ainda não desenvolvi essa estratégia. Eu vejo muitos colegas artistas que estão pensando só nisso, fazendo trabalho pra vender. Utilizando até a sua iconografia, do que levou para rua [...] isso é uma demanda que surge [...] das galerias, mas, mais das galerias, ainda, dos colecionadores. Que sabem [...] É arte contemporânea. ${ }^{23}$

Além de mostrar o aumento da demanda pela obra dos grafiteiros, essas diferentes frentes de trabalho podem ser interpretadas como resultado da falta de regularidade de trabalho e de renda e da ausência de regulamentação da profissão.

Neste contexto, de um lado está o poder público, que tenta "enquadrar" os grafiteiros através de normatizações, mas esbarra na carência ou ineficiência regulatória, submetendo os artistas a diferentes diretivas político-administrativas, típicas das alternâncias nas gestões municipais, comumente "cobrindo" as obras com a conhecida "tinta cinza". De outro lado, estão interesses privados, que respondem à popularização do graffiti tornando-o passível de comercialização e de incorporação a espaços originalmente "estranhos" a ele, como museus e galerias, chegando a transformá-lo em objeto para colecionadores. 
24. Brasil (2011).

25. Silva (2008, p. 135).

26. Silva e Silva (2010).

27. Bianchi (2016).

28. "Políticas públicas": entendidas como "colocar o governo em ação e/ou analisar essa ação (variável independente) e, quando necessário, propor mudanças no rumo ou curso dessas ações (variável dependente)" (Souza, 2006, p. 26).

29. Prefeitura de São Paulo (1986).

\section{AVANÇOS E RECUOS: CONFLITOS E NORMATIZAÇÃO}

No Brasil, o ato de grafitar é considerado legal pela Lei n 12.408, de 25 de maio de $2011,{ }^{24}$ que alterou o artigo 65 da Lei n 9.605, de 12 de fevereiro de 1998, descriminalizando a atividade. Por outro lado, a lei deixou claro que pichar é crime, com penalidades que vão de multas a detenção. Com a alteração da lei que criminalizava o graffiti, portanto, foram dadas as condições para que $\circ$ ato de grafitar pudesse ser disseminado no Brasil em diferentes frentes.

Em outros locais, como Barcelona, o poder público tem que autorizar a obra: abre-se um processo em que consta a proposta, o espaço e um esboço, e os murais autorizados são restritos. ${ }^{25}$ Obras feitas sem autorização resultam em multas. No caso de Córdoba, na Argentina - país em que o graffiti tem muito de sua manifestação associada aos movimentos de resistência política, o município proíbe desenhos, "pegatinas" (lambe-lambe) e publicidade não autorizadas em espaços públicos. A cidade conta ainda com o programa Paredes Limpias, que cobre de branco as manifestações não autorizadas, mas promove ações de artistas sob a supervisão das autoridades públicas. ${ }^{26}$

No Brasil, mesmo com a descriminalização estabelecida pela lei federal, o ato de grafitar ainda está sujeito a leis municipais. Na cidade do Rio de Janeiro,

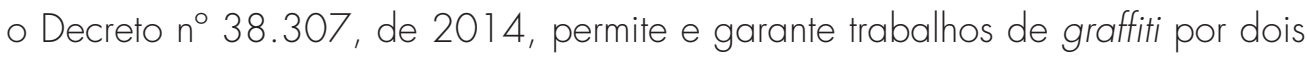
anos, desde que intempéries e acidentes não degradem a obra. Os graffitis devem ser realizados em locais previamente autorizados, como postes, colunas, muros cinza (com exceção de patrimônio histórico), empenas cegas, pistas de skate e tapumes de obras. ${ }^{27}$

No caso da cidade de São Paulo, há mais ou menos três décadas ocorrem tentativas de se estabelecer um diálogo entre grafiteiros e gestores públicos com vistas à elaboração de políiticas públicas ${ }^{28}$ que englobem o graffiti, em um processo com avanços e recuos.

As primeiras manifestações nesse sentido começaram com Jânio Quadros (1986-1988), primeiro prefeito eleito de São Paulo depois da Ditadura Militar, o qual instituiu por meio da Lei n ${ }^{\circ}$ 10.237, de 17 de dezembro de 1986, ${ }^{29}$ a Comissão de Proteção à Paisagem Urbana (CPPU), com o objetivo de controlar a ocupação do solo e regulamentar imóveis e construções, proteger a paisagem e o meio ambiente e controlar o desenvolvimento urbano. A lei foi uma das primeiras iniciativas de políticas públicas voltadas à regulamentação da paisagem urbana. 
A sucessora de Jânio, Luiza Erundina (1989-1992), estabeleceu um bom diálogo entre grafiteiros e a Secretaria da Cultura, promovendo avanços. Entretanto, durante as gestões de Paulo Maluf (1 993-1996) e Celso Pitta (1997-2000), muitos graffitis foram apagados e sobrepostos com tinta cinza, demonstrando a falta de interesse do poder público em estabelecer diálogo com os grafiteiros. Essa situação só melhorou na gestão de Marta Suplicy (200 1-2004), que, segundo Amaral, criou um dos "melhores projetos de políticas públicas para o graffiti", com eventos e produção de murais pela cidade. ${ }^{30}$

Na gestão de Gilberto Kassab (2006-2012), as competências da CPPU foram ampliadas com a promulgação da Lei n 14.223, a "Lei Cidade Limpa"31, que embora tivesse como objeto o tratamento de anúncios e propagandas, também propunha como objetivo a ordenação da paisagem urbana. Por paisagem urbana se estabeleceu todo o espaço aéreo e toda superfície externa de qualquer elemento construído ou natural da cidade, compreendendo edifícios, construções, superfícies de infraestrutura, anteparos, fauna e flora, sinalização urbana etc. Vale ressaltar que a paisagem extrapola os elementos de um espaço, estimulando sentimentos, criando identidades e sonhos. Ela pode, portanto, estimular estilos, percepções e comportamentos de consumo.

Despertar o devaneio aparece hoje como uma qualidade simples e corriqueira, quando se estabelece uma relação com uma paisagem que se considera distintiva ou especial. A paisagem passa a ser única e inconfundível e, ao mesmo tempo, capaz de provocar alterações sensíveis. ${ }^{32}$

Dessa forma, a regulamentação, com seu foco sobre a paisagem, tinha como intenção deixar a cidade menos polvída visualmente, como afirmou o secretário executivo da CPPU, Guilherme Nafalski, em entrevista para esta investigação realizada no final de 2016 . Segundo Nafalski, a lei procura evitar a propaganda ostensiva. ${ }^{33}$

A penalidade para os anúncios ou murais causadores de poluição visual, segundo a Lei Cidade Limpa, ${ }^{34}$ não envolvem detenção, mas a aplicação de multas e a retirada do anúncio ou mural. Sob a prerrogativa da lei, é possível interpretar que tanto as pichações quanto os graffitis podem ser vistos como polvição visual, estando sujeitos a serem apagados pela administração pública, especialmente se executados sem autorização.

Como mostra o documentário Cidade Cinza, o governo de Kassab contratou uma empresa terceirizada para apagar os graffitis e pichações de rua.
30. Amaral (2014).

31. Prefeitura de São Paulo (2006).

32. Pimenta (2016, p. 874).

33. Nafalski (2016).

34. Prefeitura de São Paulo (2016). Em nenhum momento, a lei cita efetivamente o graffiti, apenas "arte pública". 
35. Cidade Cinza (2013).

36. Paço das Artes (2016).

37. Deodoro (2014).

38. Técnica usada para aplicar um desenho, figura, número ou símbolo utilizando aplicação de tinta através do corte ou perfuração em papel ou acetato.

39. Colagem de pôster artístico em espaços públicos.

40. Arte realizada fora dos espaços tradicionalmente reservados a ela, como museus e galerias. Embora se refira a espaços públicos, esse termo também é utilizado para interferências artísticas em locais privados, como aeroportos e hospitais. Ela é acessível fisicamente e modifica $o$ ambiente, sendo geralmente associada à tendência da arte contemporânea, que se relaciona com as pessoas $\mathrm{e}$ com o ambiente urbano e natural (Enciclopédia Itaú Cultural, 2016).
A escolha por se apagar ou não dependia do entendimento dos funcionários da Prefeitura e do auxiliar de gabinete da subprefeitura sobre arte. Um exemplo de apagamento ocorrido na ocasião, em 2008, foi o de um dos murais na calçada da avenida 23 de Maio, com cerca de $700 \mathrm{~m}^{2}$ de graffiti, fruto de parceria dos grafiteiros Os Gêmeos, Nina Pandolfo e Nunca. A sobreposição do mural com tinta cinza gerou repercussão negativa devido à perda de um grande painel de arte. $\bigcirc$ fato levou a Prefeitura a vir a público declarar que o apagamento foi um equívoco e convidar os grafiteiros a fazer uma nova obra no mesmo lugar. Apesar do "equívoco", a Prefeitura não quis arcar com os custos para a produção do novo mural de graffitit, cabendo à Associação Comercial de São Paulo patrocinar a nova obra. ${ }^{35}$ A questão da avaliação do que seria ou não arte, no que tange à grafitagem, será tratada adiante.

Quanto a incentivos, em 201 1, durante a gestão Kassab, teve início o Museu Aberto de Arte Urbana (MAAU), na avenida Cruzeiro do Sul. A parceria, motivada pela detenção de onze artistas que estavam grafitando o local sem autorização, foi uma parceria entre a Secretaria da Cultura do Estado e o Paço das Artes. Dentre os detidos estavam Binho Ribeiro e Chivitz, que idealizaram e realizaram o projeto, seis meses após o ocorrido. ${ }^{36} \mathrm{O}$ objetivo foi incentivar graffitis nas pilastras que sustentam o viaduto sobre a avenida; para tanto, o governo se comprometeu a trocá-los anualmente.

Durante a gestão do prefeito Fernando Haddad (2013-2016), mais especificamente em 2013, foi reapresentado à Câmara o Projeto de Lei (PL) n 840 , que propunha estabelecer parâmetros para a grafitagem. Mas até fevereiro de 2017 o PL ainda não havia sido aprovado. Voltaremos a essa questão adiante. Em 2014, Haddad aprovou a participação popular na CPPU, conforme publicado no Plano Diretor Estratégico da Prefeitura (2014), o que representou uma valorização da participação popular em assuntos relacionados à cidade e a anúncios e manifestações artísticas.

Durante a gestão Haddad também houve a promessa de se criar uma nova política pública para a grafitagem, por meio da formação de uma comissão para cuidar especialmente da arte de rua na cidade. ${ }^{37}$ Essa comissão seria formada por representantes da Prefeitura, grafiteiros, artistas que trabalham com estêncil, ${ }^{38}$ lambe-lambe ${ }^{39}$ e especialistas em urbanismo, com o intuito de promover a interação entre artistas e criar melhores estratégias para integrar a arte urbana, ou arte pública, ${ }^{40}$ com a cidade.

A gestão do prefeito João Dória Júnior (2017), contudo, inaugurou um novo capítulo de conflitos em relação ao graffiti. Assim que assumiu a Prefeitura, o 
prefeito deu início ao programa Cidade Linda e, entre as ações, ele pintou de cinza os murais de graffiti da avenida 23 de Maio, sob a alegação de que estavam deteriorados por pichações.

$\bigcirc$ prefeito, que iniciou pessoalmente a pintura com tinta cinza (como parte de seu marketing político), chegou a declarar que o fez em uma área três vezes maior que a prevista, "para dar a demonstração de apoio à cidade e repúdio aos pichadores". ${ }^{41} \bigcirc$ episódio gerou polêmica, envolvendo não somente os grafiteiros, mas também outros setores da sociedade, inclusive fomentando uma onda de pichações e grafitagens pela cidade como forma de protesto. Em uma dessas manifestações, registrou-se a seguinte mensagem: "não dê vexame, São Paulo não é Miami", numa alusão à transformação da cidade em outra, mais próxima da preferência e realidade social do prefeito.

Com o início dos apagamentos, uma ação popular foi impetrada. Em caráter liminar, a decisão proibiu a Prefeitura de dar continuidade ao apagamento dos graffitis e apontou ainda que graffitis só poderiam ser apagados com autorização do Conselho Municipal de Preservação do Patrimônio Histórico, Cultural e Ambiental de São Paulo (Conpresp).

A ação se baseou no argumento de que apagamentos foram realizados sem critérios técnicos, causando "irreparável dano paisagístico e cultural" à cidade. Em sua defesa, a Prefeitura argumentou que não cabia ao Conpresp gerir ou definir questões relacionadas ao graffiti, mas à CPPU. ${ }^{42}$ A liminar foi revogada dias depois, segundo a magistrada que a julgou, devido ao fato de a CPPU indicar o esgotamento temporal da autorização dada por ela mesma, ou seja, em função do estado dos murais, degradados por pichações ou desgastados pela emissão de gases dos veículos. ${ }^{43}$

Um dos desdobramentos gerados pelo conflito foi a aprovação, pela Câmara Municipal, em fevereiro de 2017, de uma lei que determinou multa aos detidos em flagrante por pichação. Os grafiteiros foram excluídos de punições desde que as obras fossem autorizadas pelos órgãos públicos ou, em caso de espaço privado, pelo proprietário do muro ou empena. Em outra medida, a Prefeitura anunciou o programa Museu de Arte de Rua, com o objetivo de incentivar a grafitagem em áreas determinadas pelo poder público. Pela proposta, a Prefeitura escolheria os grafiteiros através de uma comissão montada pela Secretaria Municipal de Cultura com participação de artistas, críticos e especialistas na área.

No que diz respeito à legislação específica sobre o graffiti na cidade de São Paulo, até fevereiro de 2017 ainda tramitava na Câmara Municipal o PL n ${ }^{\circ}$ $840 / 2013,{ }^{44}$ apresentado pelo vereador Nabil Bonduki, arquiteto e urbanista,
41. El País (2017).

42. G1 (2017).

43. Agência Brasil (2017).

44. Prefeitura de São Paulo (2013). 
que propunha reconhecer a prática do graffiti como manifestação artística de valor cultural, realizada com o objetivo de valorizar o espaço público ou privado, desde que sem caráter publicitário e/ou mensagens com conteúdo ilegal, preconceituoso, racista, pornográfico ou ofensivo a grupos religiosos, étnicos e culturais. Além disso, segundo o projeto, seria possível executar obras em espaços públicos e, uma vez realizada, a intervenção não poderia ser apagada ou danificada; segundo o PL, se porventura algum dano viesse a ocorrer devido a atos da administração municipal ou por empresa terceirizada prestadora de serviço público, os artistas deveriam ser ressarcidos dos prejuízos e a obra refeita.

Uma lei com essa finalidade poderia representar um passo para a legitimação do trabalho artístico dos grafiteiros e sua regulamentação, dando imunidade às obras e inibindo, pelo menos em termos legais, que ações públicas baseadas, por exemplo, na Lei Cidade Limpa pudessem resultar em graffitis apagados arbitrariamente. No entanto, ainda há ressalvas sobre o PL, tanto por parte de grafiteiros quanto por parte de administradores públicos que atuam no meio, o que revela a necessidade de se aprofundar o debate.

Um dos pontos que chama atenção nessa discussão diz respeito à autonomia do artista na composição de sua obra frente a um processo de classificação do que seria propício e/ou aceitável para receber a aprovação da Prefeitura em termos de grafitagem - problemática que será abordada adiante.

Enquanto o debate não avança, a Lei Federal n 12.408/11 e a Lei Cidade Limpa direcionam as ações dos grafiteiros em São Paulo, permitindo que muitos deles conquistem visibilidade para atuar e comercializar seus serviços, desde que com negociação e autorização prévia do responsável/proprietário do espaço a receber o graffiti. Porém, ainda há limitações e problemas nessas balizas legais.

\section{O GRAFFITIE A LEI CIDADE LIMPA}

Como resultado de um mapeamento sobre os projetos que regulamentariam a prática do graffiti na cidade de São Paulo, percebemos que a questão central na discussão é a preocupação de como se classificar e/ou determinar o que seria propício e/ou aceitável para receber aprovação da Prefeitura, através da CPPU, especialmente tendo em vista a consagração de grafiteiros com técnicas complexas e refinadas, que ganharam fama, reconhecimento e aceitação não só em espaços públicos, mas também em espaços típicos da arte contemporânea. Este 
reconhecimento acabou por direcionar a consideração de tal ou qual estética como a "ideal", como explica Savarese:

Não obstante, foi essa consagração dos grafiteiros e a valorização estética da linguagem do graffiti dentro do circuito da arte contemporânea um dos fatores que favoreceu e possibilitou a construção de uma imagem e um discurso em torno do graffiti, de acordo com os quais operariam as políticas públicas e a opinião mais geral da sociedade. ${ }^{45}$

Em outras palavras, os indivíduos encarregados de avaliar as submissões de obras estariam em condições de considerálas de modo isento, independente de padrões difundidos por nomes de destaque do meio? $\bigcirc$ que seria ou não arte? Mesmo aparentando tratar-se de uma boa iniciativa, as balizas estabelecidas e a execução do projeto ainda trazem questionamentos sobre a legitimidade desse tipo de intervenção estatal. ${ }^{46}$ Ainda mais ao se considerar que a tinta cinza utilizada para cobrir os graffitis e pichações, tão característica da gestão Kassab, não foi abandonada na gestão Haddad, e muito menos na gestão Dória. Ela continuou cobrindo obras que não passaram pelo crivo e aprovação da Prefeitura, e em alguns casos inclusive em obras autorizadas.

problema, para Savarese, ${ }^{47}$ é a possibilidade de o graffiti enquanto obra de arte, ser apropriado por governos com a finalidade de integrar políticas públicas, de forma que somente obras esteticamente "aceitáveis" sejam aprovadas e legalizadas, de modo a embelezar espaços públicos e valorizar o centro e locais estratégicos da cidade, visando atrair turistas ou atender interesses de agentes da própria administração. Já obras mais subversivas, de caráter mais "agressivo" e estética menos aceita, incompatíveis com as intenções do gestor público, seriam tratadas como "sujeira" e não aceitas como graffiti.

Moraes ${ }^{48}$ também entende que, embora bem-intencionadas, políticas públicas envolvendo o graffiti parecem não abranger as reais necessidades dos pichadores e grafiteiros, que continuam sendo enquadrados pela polícia ao realizar graffitis não autorizados.

Um caso diferente, mas que expressa a complexidade dessa relação e ajuda a refletir sobre tal problemática, aconteceu em Salvador, com o projeto Grafita Salvador, em 2005. O objetivo era promover, por meio do grafiti, a inclusão social de jovens e adolescentes, que participavam de oficinas de artes e cursos de extensão e grafitavam áreas da cidade, recebendo bolsa-auxílio por quatro horas diárias de atividades, vale-transporte e tíquetes-alimentação. A questão é que as temáticas dos graffitis e as áreas destinadas a grafitagem eram definidas
45. Savarese (2013, p. 16).

46. Savarese (2013, p. 1617).

47. Savarese (2013).

48. Moraes (2013). 
49. Ivo (2007). O projeto foi desenvolvimento pela $\mathrm{Sec}$ retaria d e Desenvolvimento Social e pela Limpurb, com apoio da empresa Sherwin-Williams no início do projeto. As atividades de artes eram oferecidas pela Escola de Belas Artes da Universidade Federal da Bahia (Ufba).

50. Lefebvre (2001, p. 105).

51. Jahnel (2016). pelo poder público, a fim de sobrepor pichações. De acordo com Ivo, apesar da boa intenção, o programa limitava os grafiteiros ao predefinir o tema e o local das obras (que muitas vezes não se integravam à paisagem, tornando-as estáticas), tolhendo a capacidade criadora dos jovens e padronizando suas ações. ${ }^{49}$

Assim, a questão é como estimular a expressão artística dos grafiteiros através de mecanismos públicos (como editais ou políticas públicas), em meio à carência/ineficiência da legislação, muitas vezes arbitrária. E como fazer isso sem direcionar a composição e o local das obras segundo interesses turísticos, paisagísticos e políticos da administração, sem "domesticar" a manifestação artística de modo tolher a liberdade de expressão e a criatividade dos cidadãos?

Por outro lado, há que se considerar o dilema entre o que é arte e o que é "sujeira" ou "vandalismo" na opinião daqueles que analisariam as submissões, dado que estes não estão excluídos dos diferentes aspectos da vida social, vivenciando realidades, necessidades, complementaridades e percepções sobre a cidade. Estas, por sua vez, são "socialmente elaboradas" e ressignificadas de acordo a realidade e a visão de mundo de cada indivíduo.

\footnotetext{
Através dessas necessidades especificadas vive e sobrevive um desejo fundamental, do qual o jogo, a sexualidade, os atos corporais tais como o esporte, a atividade criadora, a arte e o conhecimento são manifestações particulares e momentos que superam mais ou menos a divisão parcelar dos trabalhos. ${ }^{50}$
}

Essas questões, contudo, foram refutadas por Marília Jahnel, coordenadora de Promoção do Direito à Cidade da Secretaria Municipal de Direitos Humanos e Cidadania da Prefeitura de São Paulo durante a gestão Haddad. Jahnel enfatizou que, na visão daquele governo, o graffiti representava um elemento de ressignificação dos espaços públicos, capaz de estabelecer uma nova relação da sociedade com esses locais. Segundo a ex-coordenadora, as políticas públicas e os editais tinham como propósito incentivar e financiar a prática do graffiti sem fixar pré-requisitos. ${ }^{51}$

O que caberia então à Prefeitura, por intermédio da CPPU, no processo de autorização ou não de um mural de graffiti? Quais seriam seus limites de atuação? Vale lembrar que a atuação da CPPU então se fundava nas prerrogativas da Lei Cidade Limpa, tendo a função de regular a promoção do ordenamento da paisagem urbana e inibir a poluição visual e os anúncios indevidos.

Eis a questão: segundo Jahnel, naquele momento, ao contrário do que se poderia imaginar, o critério para se decidir pela concessão ou não de autorização 
para a grafitagem não se fundamentava em valores sociais subjetivos ${ }^{52}$ de membros da CPPU. O critério, segundo ela, seria o mais objetivo possível: se há ou não alguma exploração econômica do graffiti, isto é, se haveria algum tipo de divulgação de marcas por meio das obras. Não havendo exploração econômica, a CPPU autorizava a grafitagem: "Ela [a CPPU] não faz uma leitura estética ou de quem é o autor [...] ela não faz essa leitura de mérito ou estética da questão. ${ }^{53}$

Esse requisito é fundamental pois, como esclarece Jahnel, a administração pública não pode permitir que o patrimônio público seja utilizado para promover interesses particulares, como prevê a Lei Cidade Limpa, sendo função do município proibir anúncios indevidos e abusivos.

\section{O GRAFFITI E O MERCADO}

A relação entre arte e mercado, cultura e incorporação das manifestações culturais pelo capital foi tratada inicialmente por pensadores da Escola de Frankfurt, como Horkheimer e Adorno, na década de 1940. Eles definiram a expressão "indústria cultural", dando origem a um debate ainda em discussão. Adorno e Horkheimer consideravam que as artes, ao serem incorporadas pelo capital, tomavam aspecto de mercadoria, transformando-se em negócio. Por esta razão, a terminologia "indústria cultural" abarcava a padronização como forma de produção de manifestações artísticas, o que resultava na perda da sua identidade e unicidade. ${ }^{54}$

Através de uma abordagem crítica, os autores argumentavam que a indústria cultural exercia importante papel na reprodução da sociedade, dada a centralidade da "cultura e da comunicação de massa" nas atividades de lazer, na socialização, e como "mediadoras da realidade social", sendo, portanto, instrumentos sociais fundamentais, capazes de espraiar seus efeitos sobre a vida das pessoas. ${ }^{55}$ Esse processo de reprodução social por um lado conteria a tentativa de reproduzir a dominação ideológica e garantir a manutenção de interesses econômicos; de outro, a tentativa de criar condições para elaborar identidades, resistências e lutas através do materialismo cultural, como indicamos. ${ }^{56}$ A incorporação do graffiti pelo mercado parece representar esse processo.

Tal incorporação, argumenta Campos, aconteceu devido ao fascínio e curiosidade despertada no meio artístico, pois o graffiti trazia em si elementos distintos das obras dos circuitos comerciais dominantes, representando o excêntrico e o marginal. Para o pesquisador, esse processo aconteceu por vias contraditórias. Por um lado, através de um movimento de "elitização" do graffiti, convertido em
52. Sobre a subjetividade envolta na discussão sobre as obras a serem aprovadas ou não, cabe destacar que são pessoas dotadas de subjetividade, como sujeitos do conhecimento, os quais detêm o singular (vivência) e o universal (conhecimento) como ferramentas de análise e de síntese, representação e significação na tentativa de explicar, descrever e interpretar a realidade e a sua vida consciente (psíquica, moral e política). Esse sujeito, assinalado pelo "eu, pessoa, cidadão e sujeito constituem a consciência como subjetividade ativa, sede da razão e do pensamento, capaz de identidade consigo mesma, virtude, direitos e verdade" (Chauí, 1995, p. 118-119).

53. Jahnel (2016).

54. Adorno (1978, p. 288); Adorno; Horkheimer (1985).

55. Kellner (2001, p. 44).

56. Kellner (2001, p. 10). 
57. Campos (2007, p. 280283). A abordagem desse autor se refere ao caso português.

58. Pimentel (2012, p. 53). expressão artística disponível para um mercado circunscrito e restrito, começando a ser exposto em galerias de arte. Enquanto isso, a grafitagem também ia sendo massificada, transformando-se em um "bem de circulação global" que atendia a interesses comerciais, inclusive de indústrias globais, como da música, da televisão, da moda etc.

Em meados dos anos 80 Chalfant e Prigoff (1987) conseguiram documentar fotograficamente a existência de diferentes exemplares de graffiti tecnicamente apurados em cidades europeias, como Londres, Paris, Copenhaga e Viena, mas igualmente na Austrália e Nova Zelândia, demonstrando que o graffiti é claramente um fenómeno transnacional.

Ainda segundo o autor, ao final da década de 1980 revistas especializadas começaram a ser editadas em grandes cidades europeias, o que revelava já naquele momento a "vitalidade desta atividade cultural em expansão". ${ }^{57}$

Ao trazer a questão para o caso brasileiro, Pimentel também indica que a absorção do graffiti pelo mercado encontra explicação em sua origem transgressora, mas colocando em evidência a relação entre o graffiti e o Estado. Este, sendo incapaz de "frear" a ação dos grafiteiros, que se amplificava e ganhava repercussão, tratou de diferenciar o graffiti da pichação, excluindo o graffiti do campo da ilegalidade (Lei n 12.408, de 25 de maio de 201 1), justamente em razão de o mercado perceber suas potencialidades econômicas.

Uma vez que o grafite era visualmente mais aceitável que a pichação e que o primeiro, por sua vez, já havia de certa forma sido incorporado ao modelo capitalista neoliberal, era com os grafiteiros que o governo deveria unir-se para combater o "mal" da pichação. Instituiu-se o grafite como "lado bom" de uma mesma moeda. ${ }^{58}$

Tenha sido ou não primordialmente para combater a pichação que o graffiti foi aceito pelo Estado, cabem novos aprofundamentos nesse sentido. Entretanto, parece inegável que sua transição à legalidade o colocou em outros patamares sociais e econômicos, tornando-o disponível ao mercado. Talvez por isso é que grafiteiros de renome tenham hoje carreiras de sucesso, com estilos reconhecidos, espaço e voz na sociedade, tornando o graffiti uma arte com ampla visibilidade e grande impacto na paisagem urbana. Vale considerar ainda que uma cidade que abriga 12 milhões de habitantes como São Paulo nos indica a potencial relação entre a abrangência da imagem e um mercado consumidor a ser explorado, ao mesmo tempo que uma lei restringe propagandas e anúncios. 
Nafalski demonstra essa convergência de interesses artísticos e comerciais, que acabam nas mãos da CPPU. Segundo ele, praticamente todos os graffitis que passaram pela CPPU foram autorizados e, por conta disso, muitas agências de propaganda perceberam a possibilidade de utilizar o graffiti como meio para promover anúncios e propagandas veladas, dados os limites da Lei Cidade Limpa:

Quase 100\% dos graffitis que passaram por aqui são autorizados. Quando eles não são autorizados? Quando eles são publicidade, porque a exposição do graffiti é muito grande, o impacto do graffiti é muito grande e aí a economia viu aí um nicho de mercado. A Lei Cidade Limpa restringiu a publicidade, poxa, mas a arte pode. Como é que eu faço as duas coisas? Como é que eu junto as duas coisas? E aí até se criou uma área pós-[Lei] Cidade Limpa, que é a tal da $\bigcirc \bigcirc H^{59}$ [...]. Tem agências especializadas nisso e a gente vem descobrindo isso ao longo do tempo... Não só o graffiti; o graffiti é parte dessa estratégia. ${ }^{60}$

Vários casos de relação entre arte/graffiti e agências de marketing são citados por Nafalski. Segundo ele, tais casos exemplificam a dificuldade de identificar apropriações comerciais. Entre as ações dessas agências, que acabam por "contornar" a Lei Cidade Limpa, está a contratação e/ou patrocínio a grafiteiros com finalidades comerciais.

Descobrimos que [há] vários [patrocinadores]. [...] Os casos da Nike, da Audi, de Game of Thrones, aquele "azinho" naquele índio... Tinha um índio azul grafitado pelo Crânio - foi o que fez o da Nike também - na Consolação, grandão... e o símbolo do cinto dele era de um jogo de videogame. A coisa é tão bem-feita, é tão discreta... que o nosso analista não precisa saber. E aí eles vêm usando desse subterfúgio para contornar a lei. ${ }^{61}$

Um desses casos foi a confecção de um graffiti em homenagem às Olimpíadas de 2016, em um dos pilares do viaduto do Minhocão. No processo, fez-se a solicitação à CPPU com a premissa de "incentivo ao esporte", mas, posteriormente, quando concretizado, o pilar foi objeto principal da propaganda da Nike pela cidade, com anúncios que traziam a foto do graffiti ao fundo, com a frase "Vem junto" (Figura 2). Dessa forma, a arte pública foi utilizada como peça publicitária, e passou despercebida pela CPPU, pois não foi possível pressupor sua intenção subliminar.

Como o próprio secretário afirma, há um nicho de mercado e um interesse econômico por parte de empresas de propaganda em utilizar o graffiti. E isso ajuda a reforçar a hipótese de que existe um setor econômico do graffiti em desenvolvimento na cidade de São Paulo. ${ }^{62}$
59. Mídia Out of Home (OOH) se refere a uma técnica de publicidade externa em que o anunciante atrai a atenção dos consumidores enquanto estes estão fora de casa, trabalhando, estudando, passeando no shopping etc. (Associação Brasileira de Mídia Out of Home, 2016).

60. Nafalski (2016).

61. Nafalski (2016).

62. Pires (2016, p. 40-63). 


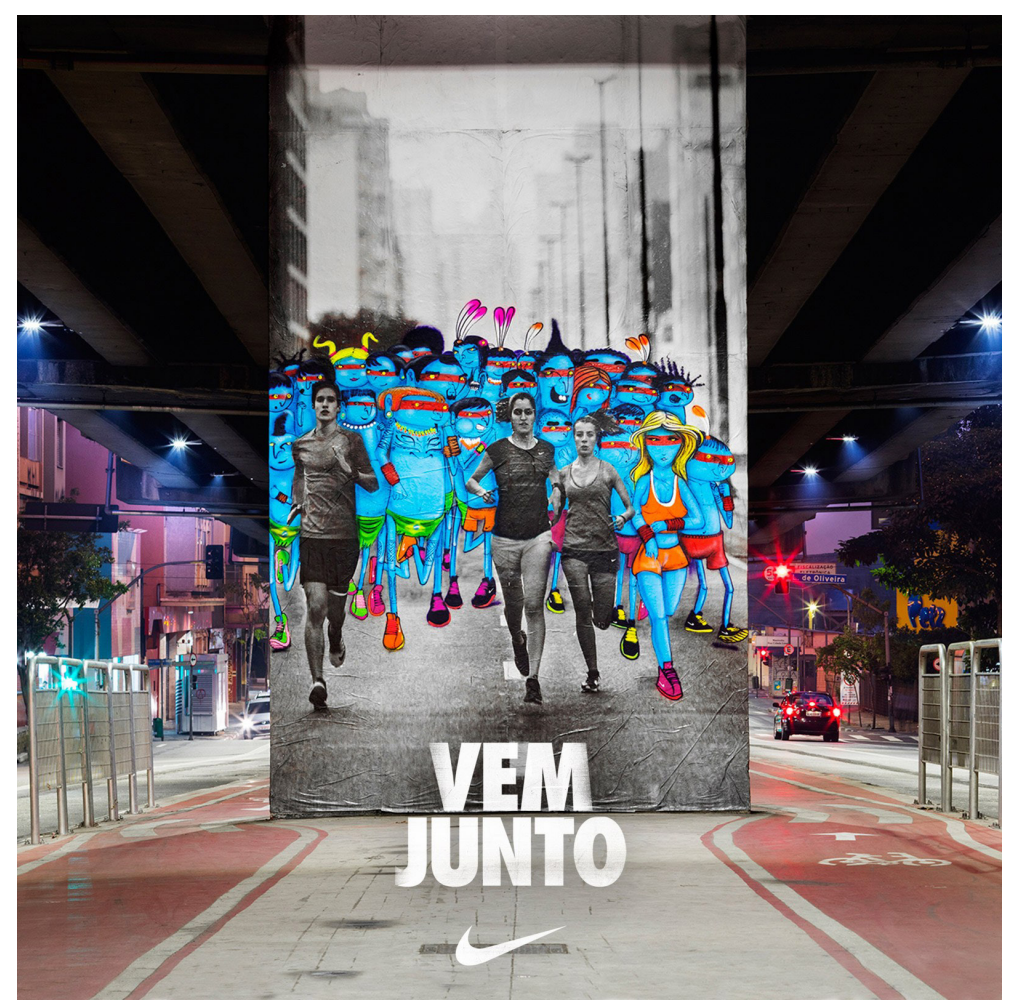

Figura 2 - Peça publicitária da Nike. Graffiti sobre o Minhocão. Graffiti de Crânio e lambe-lambe de Marmota vs. Milky. São Paulo, 2015. Fonte: site Zupi. Fotografia de Alex Takaki.

Em outro caso, a montadora Audi utilizou-se do graffiti para lançar um de seus veículos. No caso, o grafiteiro Kobra fez um graffiti com a face de Ayrton Senna em uma empena localizada numa movimentada avenida da cidade (Figura 3):

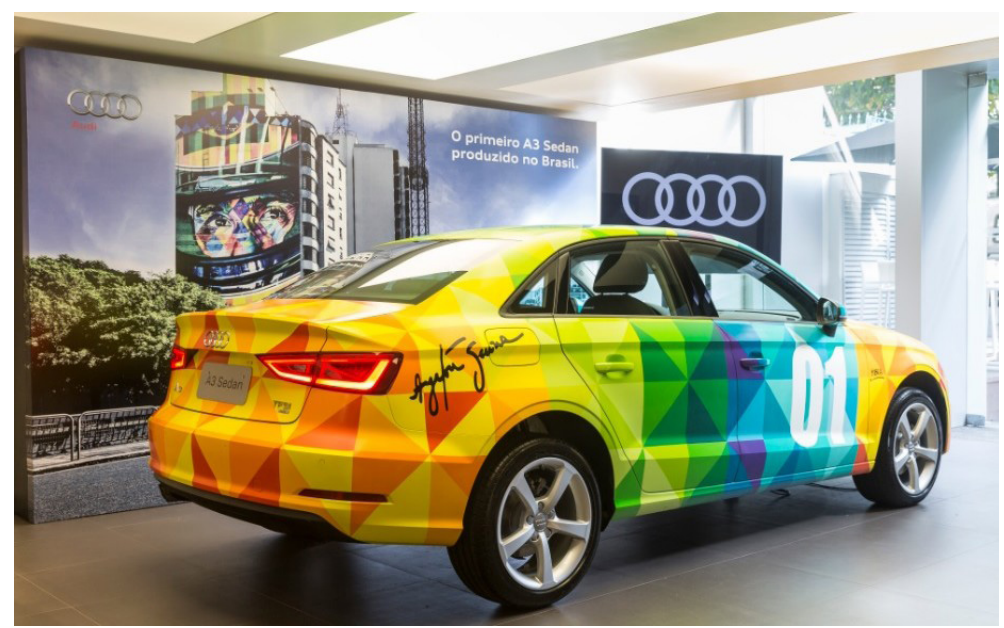

Figura 3 - Foto publicitária da Audi com graffiti do rosto de Ayrton Senna (ao fundo), encomendado pela Audi a Eduardo Kobra, 2015. Fonte: press release Audi. 
Senna, ícone brasileiro, pra uns o herói nacional. [...] Tudo bem. Quem vai falar? [O Kobra] também fez o Niemeyer lá numa outra empena. Agora o Senna, ele grafitou do mesmo jeito, e teve um carro da Audi customizado com aquele mesmo estilo, que foi leiloado pela Fundação Ayrton Senna, e a Audi fez propaganda com o graffiti de fundo, onde expunha o carro com a foto do graffiti, porque o Senna tinha uma relação com a Audi. E aí pronto, uma peça publicitária. ${ }^{63}$

Nesse mercado, as agências de publicidade têm importante papel, na medida em que estão se especializando e criando formas de comunicação com o graffiti atendendo grandes corporações. ${ }^{64} \bigcirc$ projeto Galeria GE, de 2012 , é outro exemplo dessa incorporação do graffiti aos negócios de grandes companhias. Nesse caso, destacamos a alegação da empresa:

Depois de cinco anos da implantação da Lei Cidade Limpa, que eliminou a polvição visual na cidade ao proibir o uso indiscriminado de publicidade externa, a Prefeitura começou a liberar espaços para a criação de grafites que transformarão os muros e as paredes da cidade numa enorme galeria de arte. Para oferecer um presente a São Paulo e colaborar com esta transformação, o projeto "Galeria GE" entregará suas primeiras obras este mês. ${ }^{65}$
63. Nafalski (2016).

64. Comunicação e cultura caminham juntas e, por esta razão, a cultura é intrinsecamente comunicacional, "não há comunicação sem cultura e não há cultura sem comunicação", aponta Kellner (2001, p. 53). Nesse sentido, é possível compreender a ação mercadológica no interior dessa interação socioeconômica.

65. GE Reports Brasil (2012).

66. GE Reports Brasil (2012); Meio \& Mensagem (2012); Revista Exame (2012).

projeto, idealizado pela agência de propaganda e marketing AlmapBBDO, convidou o Estúdio Colletivo, Rui Amaral e a dupla Mulheres Barbadas para realizar os painéis em empenas pela cidade. Os primeiros painéis foram desenvolvidos na rua da Consolação, na avenida Paulista e na rua Amauri, e seus temas estavam diretamente relacionados aos negócios da companhia no Brasil: transporte, energia e saúde (Figura 4).

Em etapa subsequente, foram desenvolvidos outros dois painéis com os temas água e aviação, por Glauco Diogenes e Mário Níveo, que foram escolhidos pelo público através de uma votação realizada na fanpage da Galeria GE, onde também era possível acompanhar as etapas do processo de pintura dos painéis. ${ }^{66}$
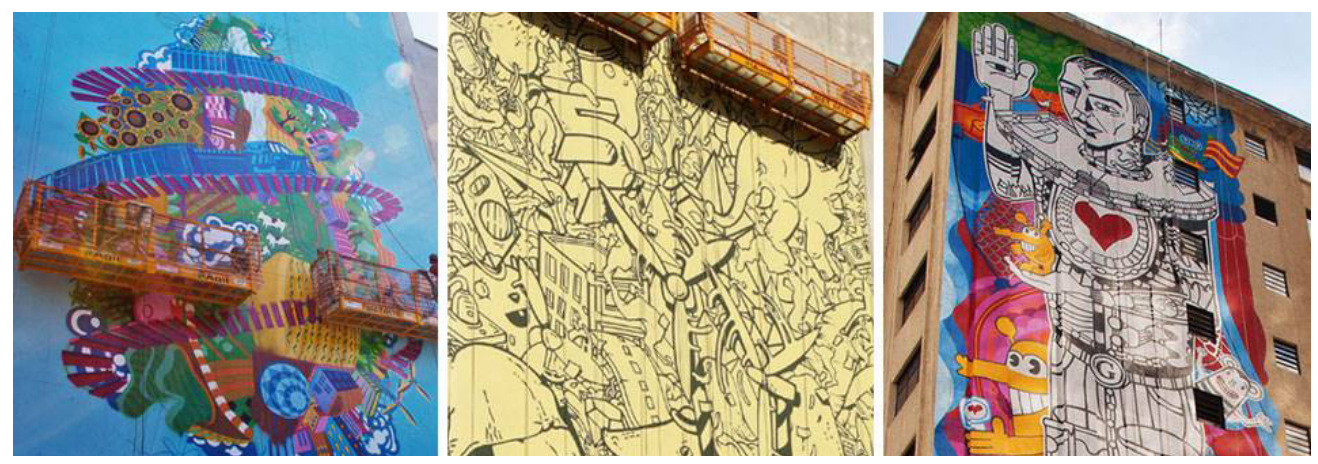

Figura 4 - Graffitis da Galeria GE, com os temas Transporte, Energia e Saúde, na rua da Consolação, na Avenida Paulista e na rua Amauri, São Paulo, 2012. Colaboração do Estúdio Colletivo, Rui Amaral e Mulheres Barbadas. Fonte: GE Imprensa Brasil. 
Tais exemplos, portanto, revelam a relação estabelecida entre um setor em processo de afirmação e desenvolvimento e interesses privados, expressos através de agências de publicidade e grandes corporações, que têm se apropriado do graffiti para promover suas comunicações corporativas. No centro dessa interrelação, contudo, há grafiteiros e todo um setor atuando, aumentando renda e disseminando a arte do graffiti.

\section{CONSIDERAÇÕES FINAIS}

A partir da hipótese de que havia em fins de 2016 e início de 2017 uma economia do graffiti na cidade de São Paulo, este artigo procurou compreender a origem, a difusão e as especificidades dessa manifestação artística e o modo como ela se relaciona com a sociedade, o poder público e o setor privado.

Postas estas inter-relações, detectamos as dinâmicas que expressam avanços e recuos nas relações entre graffiti e setores público e privado na cidade de São Paulo. Na relação com os poderes públicos (fenômeno, aliás, que não é exclusivo da capital paulista), em que a reduzida normatização que define a prática apresenta insegurança, sendo muitas vezes passível de questionamentos, há a preocupação com o direcionamento da manifestação artística, que tem em suas raízes a marca da transgressão, da subversão e da independência. Se, por um lado, o $\mathrm{PL} n^{\circ} 840 / 2013$ pode conferir uma relativa segurança à obra quando executada, afastando o uso indiscriminado da tinta cinza, ele também não deixa de ser alvo de críticas quanto a possíveis cerceamentos criativos. Da mesma forma, a utilização do grafiti em programas ou projetos sociais, aparentemente bemintencionados, também é apontada como possível mecanismo de ajuste da ação de grafiteiros, impondo interesses de agentes públicos.

Por outro lado, há que destacar a dificuldade de identificar ou qualificar o que seria arte, com ou sem mensagens subliminares ou comerciais, nas propostas submetidas à CPPU. Em outras palavras, o que verificamos é que a inexistência de uma normatização específica para o graffiti em São Paulo revela que o segmento está sujeito a formas e direcionamentos políiticos de cada gestor municipal; isto é, as políticas públicas dependem de como cada prefeito encara o graffitit, o que seria arte etc.

Quanto ao setor privado, é evidente a relação estabelecida com o graffiti, desde suas primeiras incorporações a galerias e museus, atraindo colecionadores de arte, até sua "descoberta" como instrumento de comunicação (moda, música, 
propaganda). Não por acaso, é cada vez mais comum que grandes companhias utilizem o graffiti para divulgar suas marcas e produtos.

Os casos aqui retratados, em que o graffiti é incorporado por empresas e agências de publicidade a fim de contornar a Lei Cidade Limpa, revelam tanto o sucesso dessa manifestação artística quanto seu potencial de comunicação, influência e inserção social. Essa incorporação pode ser interpretada como uma forma de "criação de condições apropriadas para a renovação da acumulação", 67 já que a proibição da propaganda (por conta da Lei Cidade Limpa) "dificultou" a propaganda urbana numa metrópole.

De qualquer forma, nos últimos anos, parece inegável que alguns incentivos (públicos e privados) resultaram em reconhecimento por parte de alguns gestores públicos e da população quanto à relevância do graffiti do ponto de vista artístico e econômico. Não em vão, esse processo de valorização do graffiti pela sociedade tem despertado setores do mercado que buscam incorporar essa manifestação artística e sua imagem como estratégia de marketing para divulgar marcas e produtos. ${ }^{68}$

Mesmo diante da volatilidade de movimentos ora de incentivo ora de desestímulo por parte de gestores públicos, cada vez mais o graffiti é encarado não apenas como forma de manifestação artística, mas também como estratégia de negócios. Da mesma forma, é inegável a existência de grafiteiros que se integraram ao mercado, enquanto outros resistem a ele.

De qualquer modo, o que parece evidente é que nos últimos anos, guardadas as devidas especificidades, os grafiteiros possuem mais alternativas para executar seus trabalhos e atender diferentes demandas, e que este processo nada mais é do que fruto de seu sucesso e reconhecimento. Esse processo, por sua vez, também deixa evidente que o poder público deve se capacitar para gerir a prática do graffiti, seja por meio das prerrogativas da Lei Cidade Limpa ou por qualquer outra lei municipal que direcione as balizas para a grafitagem na cidade de São Paulo. Vale destacar que somente uma gestão verdadeiramente democrática, que se debruce especificamente sobre a arte urbana, poderá levar a reais avanços nas políticas direcionadas ao segmento.

Por fim, cabe ressaltar que a democracia remonta à esfera pública e transparente do debate, propícia ao exercício do contraditório. Aliás, simbolicamente, foi no espaço público da rua que o graffiti se originou, conquistou seu lugar ao sol, suas condições de difusão, voz e expressão. No espaço público, como esfera capaz de gerar resistências e difundi-las, é que se deram, e se dão, os embates entre grafiteiros e as diferentes gestões municipais, que muito utilizaram, e ainda utilizam, a tinta cinza. E justamente porque conquistou o espaço público, o graffiti despertou a atenção do mercado (sob a lógica capitalista), que vislumbrou a chance de utilizá-lo como ferramenta atrativa de negócios e comunicação.
67. Harvey (2005, p. 45)

68. Em fevereiro de 2017, Kobra preparava-se para iniciar a pintura de um painel de 5.742 metros quadrados, em uma empresa de chocolate, situada na Rodovia Castelo Branco, em Itapevi. A previsão era que o mural se tornaria o maior mural de graffiti do mundo (O Estado de S.Paulo, 2017). 


\section{REFERÊNCIAS}

FONTES IMPRESSAS

FBRASIL. Lei n ${ }^{\circ}$ 12.408, de 25 de maio de 2011. Diário Oficial da União, Brasília, DF, 26 maio 2011. Seção 1, p. 1.

PREFEITURA DE SÃO PAULO (SP). Lei $n^{\circ}$ 10.237, de 17 de dezembro de 1986. Reestrutura a Secretaria da Habitação e Desenvolvimento Urbano, cria os cargos correspondentes, e dá outras providências. Secretaria do Governo Municipal, publicado em 17 de dezembro de 1986.

Lei $n^{\circ}$ 14.223, de 26 de setembro de 2006. Dispõe sobre a ordenação dos elementos que compõe a paisagem urbana do município de São Paulo. Secretaria do Governo Municipal, publicado em 26 de setembro de 2006.

LIVROS, TESES E ARTIGOS

ADORNO, Theodor W. Indústria cultural. In: COHN, Gabriel (Org.). Comunicação e indústria cultural. São Paulo: Companhia Editora Nacional, 1978.

ADORNO, Theodor W.; HORKHEIMER, Max. A dialética do esclarecimento: fragmentos históricos. Tradução Guido Antonio de Almeida. Rio de Janeiro: Jorge Zahar, 1986.

BOEMER, Otávio. Grafite como meio: processo de criação entre sistemas: a lei, a rua, o mercado e a pesquisa em arte. 2013. 225 f. Dissertação (Mestrado) - Instituto de Artes, Universidade Estadual Paulista Júlio de Mesquita Filho, São Paulo, 2013.

CAMPOS, Ricardo Marnoto de Oliveira. Pintando a cidade: uma abordagem antropológica ao grafite urbano. 2017. 510 f. Dissertação (Doutoramento em Antropologia) - Universidade Aberta, Lisboa, 2007. Disponível em: <https://repositorioaberto.uab.pt/handle/10400.2/765>. Acesso em: 11 jun. 2018.

CHAUÍ, Marilena. Convite à filosofia. 5. ed. São Paulo: Ática, 1995. 
DEODORO, Juliana. Prefeitura vai criar política pública para grafite em São Paulo. Veja São Paulo, São Paulo, jul. 2014. Disponível em: <http://vejasp.abril.com.br/materia/prefeiturapolitica-publica-grafite-sao-paulo>. Acesso em: 10 set. 2016.

GITAHY, Celso. O que é grafite. São Paulo: Brasiliense, 1999.

HARVEY, David. A produção capitalista do espaço urbano. Trad. Carlos Szlak. São Paulo: Annablume, 2005.

IVO, Any Brito Leal. Cidade-mídia e arte de rua. Caderno CRH, Salvador, v. 20, n. 49, p. 107-122, 2007.

KELLNER, Douglas. A cultura da mídia-estudos culturais: identidade e política entre o moderno e o pós-moderno. Tradução Ivone Castilho Benedetti. Bauru: Edusc, 2001.

LEFEBVRE, Henri. O direito à cidade. Tradução Rubens Eduardo Frias. São Paulo: Centauro, 2001.

MORAES, Priscila Pereira de. Políticas Públicas para Grafite no Rio de Janeiro: painel da Praça Cardeal Câmara. In: ENCONTRO NACIONAL DE PRODUÇÃO CULTURAL, 3., Salvador, 2013. Anais. Salvador: Enprocult, 2013.

PIMENTA, Margareth Afeche. Em busca do sentimento da paisagem. Cadernos Metrópole, São Paulo, v. 18, n. 37, p. 863-878, 2016.

PIMENTEL, Marina de Oliveira. Curitiba em cores: a prática do grafite e da pichação frente ao marketing urbano da capital paranaense. 2012. 102 f. Dissertação (Mestrado) - Faculdade de Economia, Universidade de Coimbra, Coimbra, 2012.

PIRES, Elena Moraes. Grafitagem na cidade de São Paulo: arte, negócio ou ambos? 2016. 141 f. Conclusão de Curso (Graduação em Ciências Econômicas) - Universidade Federal de São Paulo, Osasco, 2016.

SALES, Ana Célica Garcia de. Pichadores e grafiteiros: manifestações artísticas e políticas de preservação do patrimônio histórico e cultural da cidade de Campinas-SP. 2007. $84 \mathrm{f}$. Dissertação (Mestrado) - Instituto de Artes, Universidade Estadual de Campinas, 2007.

SAVARESE, Victor Monteiro. O grafite como elemento ambíguo na constituição da identidade visual da cidade de São Paulo. São Paulo: Laboratório Didático Sociologia, 2013.

SILVA, Anna Lúcia dos Santos Vieira e. Grafite: Manifestação de arte urbana. Public art in urban design - On the waterfront, Barcelona, Centre de Recerca Polis, vol. 11, p. 131-141, 2008. 
SILVA e SILVA, Wiliam da. O grafite urbano contemporâneo: do Brasil e da Argentina para o mundo. In: SIMPÓSIO INTERNACIONAL DE COMUNICAÇÃO E CULTURA NA AMÉRICA LATINA, 3., São Paulo. Anais. São Paulo: 2010. p. 670-679.

História e motivações do grafite contemporâneo. Revista Nuevamérica, Buenos Aires, v. 1, p. 217-229, 2015. Disponível em: <http://docs.wixstatic.com/ugd/2064bf_8cfbebca4ab9 4fa69bd6b64d7943d6b4.pdf>. Acesso em: 19 maio 2018.

SOUZA, Celina. Políticas Públicas: uma revisão da literatura. Sociologias, Porto Alegre, ano 8, n. 16, jul./dez. 2006.

WILlIAMS, Raymond. Cultura. Tradução Lólio L. Oliveira. Rio de Janeiro: Paz e Terra, 1992.

SITES

ALBUQUERQUE, Flávia. Cai liminar que impedia a prefeitura de apagar grafites na cidade de São Paulo. Agência Brasil, São Paulo, 24 fev. 2017. Disponível em: <http://agenciabrasil.ebc. com.br/geral/noticia/2017-02/cai-liminar-que-impedia-prefeitura-de-apagar-grafites-na-cidadede-sao-paulo>. Acesso em: 18 maio 2018.

ALESSI, Gil. A “maré cinza” de Doria toma São Paulo e revolta grafiteiros e artistas. El País, São Paulo, 25 jan. 2017. Disponível em: <https://brasil.elpais.com/brasil/2017/01/24/ politica/1485280199_418307.html>. Acesso em: 18 maio 2018.

AMARAL, Rui. Por uma política pública para o grafite. Folha de S.Paulo, São Paulo, 14 dez. 2014. Disponível em: <http://www1.folha.uol.com.br/opiniao/2014/12/1561949-rui-amaralpor-uma-politica-publica-para-o-grafite.shtml>. Acesso em: 14 jun. 2016.

ASSOCIAÇÃO BRASILEIRA DE MídIA OUT OF HOME. Mídia Digital Out Of Home. 2016. Disponível em: <http://www.abmooh.com.br/midia-digital-out-of-home/>. Acesso em: 23 nov. 2016.

BIANCHI, Paula. A cidade tatuada: saiba como é a lei para grafites em SP e no Rio. UOL, São Paulo, 29 fev. 2016. Disponível em: <http://noticias.uol.com.br/cotidiano/ultimasnoticias/2016/02/29/a-cidade-tatuada-veja-grafites-em-sp-e-no-rio-e-como-e-a-lei.htm>. Acesso em: 05 nov. 2016. 
DIANA, Daniela. Grafite. Toda matéria. 2016. Disponível em: <https://www.todamateria.com. br/grafite-arte-urbana/>. Acesso em: 26 nov. 2016.

ENCIClOPÉdia ITAú CUlTURAl. Arte Pública. 2016. Disponível em: <http://enciclopedia. itaucultural.org.br/termo356/arte-publica>. Acesso em: 22 nov. 2016.

GE. GE cria galeria inovadora de arte a céu aberto em São Paulo. Assessoria de Imprensa GE, 2012. Disponível em: <http://www.geimprensabrasil.com/wp-content/uploads/2012/07/PressRelease-Galeria-GE-30.07.2012.pdf>. Acesso em: 15 de dez. 2016.

GE REPORTS BRASIL. Os vencedores do Galeria GE são... 2012. Disponível em: <http://www. gereportsbrasil.com.br/post/95917190259/os-vencedores-do-galeria-ge-sao>. Acesso em: 24 nov. 2016.

HISTÓRIA DAS ARTES. Disponível em: <https://www.historiadasartes.com/nomundo/arteseculo-20/grafite/>. Acesso em: 10 maio 2017.

MASP. Exposições: De dentro pra fora, de fora pra dentro. São Paulo, 2010. Disponível em: $<$ http://masp.art.br/masp2010/exposicoes_integra.php?id=8\&periodo_menu=2010>. Acesso em: 5 jun. 2016.

MEIO\&MENSAGEM. GE oferece galeria inovadora de arte a céu aberto para São Paulo. 2012. Disponível em: <http://portfoliodeagencias.meioemensagem.com.br/anuario/propaganda/ agencias/ALMAPBBDO/2283/portfolio-da-agencia/GE\%20oferece\%20gleri\%20inovdor\%20 de\%20rte\%20ceu\%20berto\%20r\%20So\%20Pulo/714>. Acesso em: 24 nov. 2016.

NUNES, Brunella. Os novos grafites da 23 de Maio em SP pelas lentes do Hypeness. Hypeness. São Paulo, Março de 2015. Disponível em: <http://www.hypeness.com.br/2015/03/coberturahypeness-voltamos-ao-mural-da-av-23-de-maio-para-ver-as-novidades/>. Acesso em: 5 jun. 2016.

OS GÊMEOS. 2017. Disponível em: <http://www.osgemeos.com.br/pt>. Acesso em: 20 fev. 2017.

PAÇO DAS ARTES. Notas do Paço. Para todos: $1^{\circ}$ Museu Aberto de Arte Urbana traz cor à zona norte de SP. 2008. Disponível em: <http://www.pacodasartes.org.br/notas/materia_maau. aspx>. Acesso em: 31 ago. 2016.

REVIVARTE. Revitalizando o espaço urbano por meio da arte. 2016. Disponível em: <https:// projetorevivarte.wordpress.com/sobre/>. Acesso em: 5 jun. 2016. 
PREFEITURA DE SÃO PAULO (SP). Projeto de Lei $n^{\circ}$ 840/2013, de 27 de novembro de 2013. Dispõe sobre a utilização de espaços da cidade para a arte do grafite e dá outras providências. São Paulo, Disponível em: <http://www.radarmunicipal.com.br/proposicoes/projeto-delei-840-2013>. Acesso em: 10 set. 2016.

RAFU. $1^{\circ}$ Museu Aberto de Arte Urbana do Mundo. Hypeness. São Paulo. 2011. Disponível em: <http://www.hypeness.com.br/2011/10/1-museu-aberto/>. Acesso em: 24 nov. 2016.

SÁ, Sylvia de. GE transforma painéis de São Paulo em galeria a céu aberto. Revista Exame, São Paulo, 30 jul. 2012. Disponível em: <http://exame.abril.com.br/marketing/ge-transformapaineis-de-sao-paulo-em-galeria-a-ceu-aberto/>. Acesso em: $21 \mathrm{dez}$. de 2016.

SANTIAGO, Tatiana. Justiça proíbe Dória de apagar grafite sem aval de conselho do Patrimônio Histórico e Cultural. G1, Rio de Janeiro, 14 fev. 2017. Disponível em: <https://g1.globo.com/ sao-paulo/noticia/justica-proibe-doria-de-apagar-grafite-sem-aval-de-conselho-do-patrimoniohistorico-e-cultural.ghtml>. Acesso em: 18 maio 2018.

VEIGA, Edison. Kobra prepara maior mural do mundo na Grande São Paulo. O Estado de $S$. Paulo, São Paulo, 15 fev. 2017. Disponível em: <https://sao-paulo.estadao.com.br/blogs/edisonveiga/kobra-prepara-maior-mural-do-mundo-na-grande-sao-paulo/>. Acesso em: 23 jun. 2018.

ENTREVISTAS

JHANEL, Marília. Entrevista de Marília Jhanel: grafite na cidade de São Paulo [out. 2016]. Entrevistadora: Elena Moraes Pires. São Paulo, 2016. 1 arquivo AAC (35 min.).

NAFALSKI, Guilherme. Entrevista de Guilherme Nafalski: grafite na cidade de São Paulo [set. 2016]. Entrevistadora: Elena Moraes Pires. São Paulo, 2016. 1 arquivo AAC (62 min.).

VAZ, Thiago. Entrevista de Thiago Vaz: grafite na cidade de São Paulo [out. 2016]. Entrevistadora: Elena Moraes Pires. São Paulo, 2016. 1 arquivo AAC (116 min).

FILMES E DOCUMENTÁRIOS

CIDADE CINZA. Direção de Marcelo Mesquita, Guilherme Valiengo. Produção de Marcelo Mesquita, Guilherme Valiengo, Peppe Siffredi, Raphael Bottino. Roteiro de Marcelo Mesquita, Peppe Siffredi, Felipe Lacerda. São Paulo: Sala 12 Filmes, 2013. 
EFEMERACIDADE. Direção de Wendell Sacramento e Fellipe Mandu. Produção de Fellipe Mandu. Roteiro de Wendell Sacramento. São Paulo: Centro Universitário Senac, 2013.

Artigo apresentado em 20/12/2017. Aprovado em 10/09/2018.

\section{(cc) BY}

All the contents of this journal, except where otherwise noted, is licensed under a Creative Commons Attribution License 